\title{
APLIKASI PERMAINAN SUDOKU HURUF HIJAIYAH MENGGUNAKAN ALGORITMA BACKTRACKING DAN MULTIPLICATIVE CRNG SEBAGAI PEMBANGKIT DAN PENYELESAI PERMAINAN
}

\author{
Misbakhul Mustofin, Hani Nurhayati, MT \\ Jurusan Teknik Informatika, FSaintek, UIN Maulana Malik Ibrahim Malang \\ e-mail:mr.tofin@yahoo.com
}

\begin{abstract}
ABSTRAK
Algoritma Backtracking (Runut-Balik) merupakan algoritma yang sangat baik dalam menyelesaikan permasalahan yang memiliki banyak kemungkinan karena algoritma ini tidak memeriksa semua kemungkinan yang ada. Algoritma ini hanya mempertimbangkan kemungkinan yang mengarah kepada solusi, sehingga proses pencarian menjadi jauh lebih cepat. Algoritma Multiplicative CRNG adalah algoritma pembangkit bilangan acak yang baik karena tidak membangkitkan bilangan yang sama secara berturut-turut. Pembangkit dan penyelesai permainan Sudoku Hijaiyah merupakan permasalahan yang dapat diselesaikan dengan baik menggunakan perpaduan antara algoritma Backtracking dan algoritma Multiplicative CRNG.
\end{abstract}

Kata kunci: Backtracking, Multiplicative CRNG, Sudoku

\section{PENDAHULUAN}

Al-Qur'an merupakan kitab suci Agama Islam yang diturunkan menggunakan bahasa Arab. Karena itu dalam mempelajarinya diperlukan pengetahuan mengenai bahasa Arab. Dalam mempelajari bahasa Arab diharuskan mengetahui huruf-huruf bahasa Arab terlebih dahulu. Huruf bahasa Arab biasa dikenal sebagai huruf hijaiyah. Terdapat berbagai macam cara pembelajaran, salah satunya yaitu melalui permainan.

Permainan saat ini sudah mulai beralih ke arah mobile smartphone, yang memungkinkan pemain untuk memainkan permainan dimana saja dan kapan saja. Salah satu sistem operasi mobile smartphone yang sedang berkembang saat ini adalah sistem operasi Android. Sistem operasi Android bersifat terbuka sehingga memberi kesempatan bagi para pengembang untuk menciptakan aplikasi mereka sendiri, terutama aplikasi permainan. Aplikasi permainan berkembang pesat di sistem operasi Android. Salah satu permainan yang dapat dikembangkan di sistem operasi Android adalah Sudoku.

Sudoku merupakan salah satu permainan teka-teki angka. Secara umum permainan ini berbentuk Tabel berukuran 9x9 yang di dalamnya terdapat sembilan blok/kelompok berukuran $3 \times 3$. Tujuan dari permainan ini adalah mengisi setiap kotak (sel Tabel) yang kosongdengan angka yang terdiri dari1-9 sedemikian hingga tidak terdapat pengulangan angka dalam satu blok, satu baris maupun satu kolom.

Dalam menyelesaikan permainan sudoku terdapat beberapa algoritma, salah satunya adalah algoritma backtracking (runut-balik). Algoritma backtracking berbasis pada DFS (Depth First Search). Pada algoritma backtracking, pencarian solusi lebih difokuskan pada pencarian yang mengarah ke solusi saja sehingga 
mempersingkat proses pencarian. Selain algoritma backtracking terdapat algoritma Multiplicative CRNG yang berfungsi sebagai pembangkit angka secara acak. Algoritma pembangkit angka secara acak ini cukup mudah dipahami dan diaplikasikan karena memiliki batasan yang bisa disesuaikan dengan kebutuhan.

Penelitian tentang sudoku menggunakan bahasa Arab telah dilakukan oleh Riyadli Abrar (Abrar,2012). Pada penelitian tersebut, pembangkitan dan penyelesaian permainan menggunakan algoritma Harmony Search. Penggunaan Harmony Search pada penelitian tersebut dapat menyelesaikan puzzle Sudoku dengan benar dalam waktu tercepat antara $1-15$ detik dengan jumlah kotak kosong yang terdapat dalam puzzle antara 35 - 40, 2 - 12 detik dengan jumlah kotak kosong yang terdapat dalam puzzle antara $40-$ 45 , dan 5 - 35 detik dengan jumlah kotak kosong yang terdapat dalam puzzle antara 45 - 50. Solusi tidak ditemukan pada parameter tertentu yaitu dengan parameter $\mathrm{HMS}=10$, $\mathrm{HMCR}=0.9$, dan $\mathrm{PAR}=0.1,0.5$, setelah melakukan 1000 improvisasi dalam waktu 49 - 55 detik.

Pada penelitian lain yang membahas penyelesaian permainan sudoku menggunakan algoritma Backtracking dan Elimination oleh Agustinus Tri Gunawan (Gunawan, 2010) menghasilkan waktu penyelesaian yang lebih cepat. Pada penelitian tersebut dapat menyelesaikan permainan sudoku dalam waktu 0.1 detik dengan jumlah kotak kosong yang terdapat dalam puzzle berjumlah 10, 29 dan 58.

Fungsi acak yang digunakan pada penelitian Agustinus Tri Gunawan adalah fungsi acak bawaan dari bahasa pemrograman. Penulis mencoba membangkitkan bilangan bulat acak sebanyak 10 kali menggunakan fungsi acak bawaan dari bahasa pemrograman yang akan digunakan yaitu java dengan souce code sebagai berikut:

$$
\text { int acak }=(\text { int })(\text { Math.random }() * 10) \text {; }
$$

menghasilkan output : 9, 9, 8, 1, 5, 0, $0,5,0$ dan 6 . Penulis juga melakukan uji coba pada algoritma pengacakan Multiplicative $\quad C R N G$ untuk membangkitkan bilangan bulat acak sebanyak 10 kali dengan parameter $\mathrm{a}=2, \quad \mathrm{~m}=11, \quad \mathrm{Z} 0=7$ menghasilkan output: $3,6,1,2,4,8,5,10,9$ dan 7.

Dari percobaan tersebut terlihat bahwa bilangan acak yang dibangkitkan menggunakan fungsi bawaan bahasa pemrograman masih kurang maksimal karena beberapa kali mengulang bilangan yang sama secara berturut-turut. Pada percobaan menggunakan algoritma Multiplicative CRNG tidak menghasilkan bilangan yang sama secara berturut-turut.Untuk itu pada penelitian ini tidak menggunakan fungsi bilangan acak bawaan bahasa pemrograman melainkan menggunakan algoritma Multiplicative $\quad C R N G$ sebagai pembangkit bilangan acak.

Pada penelitian ini menggunakan perpaduan antara algoritma Backtracking dan Multiplicative CRNG sebagai Generator dan Solver dari permainan sudoku yang akan dibangun dengan harapan dapat menyelesaikan permainan sudoku dengan waktu lebih cepat dan $100 \%$ solusi ditemukan. Generator digunakan untuk membangkitkan soal pada Tabel yang sudah disediakan berdasarkan level yang dipilih, sedangkan Solver digunakan untuk menyelesaikan permainan jika pemain menyerah dalam menyelesaikan permainan secara manual. Penelitian ini akan diimplementasikan pada Android OS mobile dengan harapan dapat diaplikasikan dimana saja dan kapan saja. 
1. METODE, ALAT, DAN BAHAN

Metode:

1. Backtracking

2. Multiplicative $C R N G$

Alat dan Bahan:

1. Laptop Compaq Presario V3000

2. Smartphone Android Sony Ericsson Experia X8

3. Eclipse IDE

4. Android SDK

5. Android Emulator

\section{HASIL DAN DISKUSI}

Sudah dijelaskan sebelumnya bahwa pada penelitian yang sudah dilakukan oleh Riyadli Abrar dalam menyelesaikan teka-teki Sudoku menggunakan algoritma Harmony Search menemukan solusi dalam waktu lebih atau sama dengan 1 detik. Sedangkan pada penelitian Agustinus Tri Gunawan yang menggunakan algoritma Backtracking dan Elimination dalam menyelesaikan teka-teki Sudoku mampu menyelesaikannya dalam waktu kurang dari 1 detik dengan berbagai kondisi. Namun karena menggunakan fungsi random bawaan bahasa pemrograman maka hasil acak masih kurang maksimal.

Pada penelitian ini permasalahan Sudoku diselesaikan perpaduan antara algoritma Backtracking dan Multiplicative CRNG agar dapat membangkitkan permainan Sudoku secara unik (tidak ada pengulangan teka-teki secara berturut-turut) dan menyelesaikannya dengan waktu yang cepat.

Algoritma generator:

1. Mengisi seluruh kotak puzzle menggunakan algoritma Backtracking dan disimpan sebagai solusi cadangan.

2. Menghilangkan beberapa kotak puzzle sesuai dengan level permainan secara acak menggunakan algoritma Multiplicative CRNG.

3. Menampilkan soal hasil generate.

Algoritma solver:

1. Mengisi seluruh kotak puzzle yang kosong menggunakan algoritma Backtracking secara acak menggunakan algoritma Multiplicative CRNG.

2. Jika ditemukan solusi dari inputan user, maka menampilkan hasil penyelesaian pada papan permainan.

3. Jika tidak ditemukan solusi dari masukan user, maka menampilkan penyelesaian cadangan yang telah disimpan sebelumnya pada saat pembuatan soal.

\begin{tabular}{|l|l|l|l|l|l|l|l|l|}
\hline & & & & 2 & 7 & 8 & & 5 \\
\hline & & & & & 4 & & & \\
\hline 5 & 2 & 4 & & & & 9 & 6 & \\
\hline 4 & 8 & & & 1 & 5 & 6 & & \\
\hline & & 3 & 7 & & 2 & & & \\
\hline 1 & 9 & & 8 & 4 & 6 & & & \\
\hline & 3 & 5 & & & & & & 8 \\
\hline 2 & & & & & 1 & & 9 & 6 \\
\hline & 6 & & & 3 & & 7 & 5 & \\
\hline
\end{tabular}

Gambar 1. Permainan Sudoku.

\section{KESIMPULAN}

Algoritma Backtracking dan Multiplicative CRNG merupakan algoritma yang baik untuk digunakan sebagai pembangkit dan penyelesai teka-teki Sudoku karena menghasilkan teka-teki yang unik setiap dibangkitkan dan dapat diselesaikan dengan waktu yang cepat. 
5.DAFTAR PUSTAKA

Abrar, Riyadli. 2012. Aplikasi Permainan Arabic Sudoku Menggunakan Metode Harmony Search sebagai Pembangkit dan Penyelesaian Permainan.Skripsi. Jurusan Teknik Informatika Fakultas Sains dan Teknologi UIN Maulana Malik Ibrahim. Malang.

Gunawan, Agustinus Tri. 2010. Penerapan Algoritma Backtracking dan Elimination untuk Membangun Generator dan Solver dalam Menyelesaikan Permainan Sudoku. Sekolah Tinggi Manajemen Informatika dan Komputer AMIKOM. Yogyakarta.

Izzuddin, Muhammad. 2009. Memperbaiki bacaan Al-Qur'an (Metode Tartil 12 Jam). Assalam Publishing. Solo.

L, Riani. 2010.Pembangkit Bilangan Acak. Mata Kuliah Pemodelan \& Simulasi. Jurusan Teknik Informatika Universitas Komputer Indonesia. Bandung.

Morenvino, M. Ray, I. dan Anton, S. 2006. Penerapan Algoritma RunutBalik Untuk Penyelesaian TekaTeki Sudoku.Laboratorium Ilmu dan Rekayasa Komputasi Departemen Teknik Informatika Institut Teknologi Bandung. Bandung., in press

Safaat H, Nazruddin. 2011. Android, Pemrograman Aplikasi Mobile Smartphone dan Tablet PC Berbasis Android. Informatika. Bandung.

Sari, Rina Dewi Indah. 2007. Analisis Penyelesaian Puzzle Sudoku dengan Menerapkan Algoritma Backtracking Memanfaatkan Bahasa Pemrograman Visual Basic 6.0 dan Database Microsoft Access 2003. Jurusan Teknik Informatika Sekolah Tinggi Manajemen Informatika dan Komputer (STMIK) “ASIA”. Malang.

Zeeb, Charles N. dan Patrick J. Burns. 1984.Random Number Generator
Recommendation. Department of Mechanical Engineering Colorado State University. Colorado.

Al-Qur'an dan Terjemahannya. AlJumanatul 'Ali. Bandung.

http://en.wikipedia.org/wiki/Sudoku_al gorithms, diakses pada tanggal 31 Mei 2012 pukul 14.04 